Maria BARON-PUDA ${ }^{1}$, Katarzyna WOJTYŁA ${ }^{2}$

Opiekun naukowy: Maria BARON-PUDA

DOI: https://doi.org/10.53052/9788366249844.01

\title{
ZASTOSOWANIE WYBRANYCH TECHNIK KREATYWNOŚCI W ZESPOLOWYM ROZWIĄZYWANIU PROBLEMÓW Z ZAKRESU INŻYNIERII PRODUKCJI
}

Streszczenie: Zmiany zachodzące wewnątrz organizacji oraz w jej otoczeniu powodują, że przedsiębiorstwa muszą stosować różnorodne techniki ukierunkowane na poszukiwanie nowych sposobów działania oraz rozwiązanie problemów. Związane jest to nie tylko ze znajomością koncepcji szczupłego zarządzania, ale również kreatywnością i współpracą załogi. To właśnie poprzez zespołowe podejście i twórcze techniki udaje się znaleźć najwięcej wartościowych rozwiązań. Celem artykułu jest przedstawienie wybranych metod i narzędzi kreatywnego i zespołowego rozwiązywania problemów na przykładzie przedsiębiorstwa produkcyjnego.

Słowa kluczowe: kreatywność, techniki twórczego myślenia, praca grupowa, zespołowe rozwiązywanie problemów

\section{USING SELECTED TECHNIQUES OF CREATIVITY IN TEAM SOLVING OF PRODUCTION ENGINEERING PROBLEMS}

\begin{abstract}
Summary: Due to the changes taking place in the organization, as well as in its environment, companies have to use various tools aimed at searching for new ways of operating and solving problems. This is related not only to the knowledge of lean management concept, but also to employee creativity and cooperation. Valuable solutions are developed through a team approach and creative techniques. The aim of this paper is to present selected methods, techniques and tools for creative and team problem solving on the example of a manufacturing company
\end{abstract}

Keywords: creativity, creative thinking techniques, teamwork, team problem solving

\footnotetext{
${ }^{1}$ dr inż., Akademia Techniczno-Humanistyczna w Bielsku-Białej, Wydział Budowy Maszyn i Informatyki, mpuda@ath.bielsko.pl

2 mgr inż., Akademia Techniczno-Humanistyczna w Bielsku-Białej, Wydział Budowy Maszyn i Informatyki,kw051645@student.ath.edu.pl
} 


\section{Wprowadzenie}

Każda firma produkcyjna zmaga się $\mathrm{z}$ problemami występującymi w obszarze inżynierii produkcji, w tym np. w procesach planowania, wytwarzania, logistyki, sprzedaży. Problem można zdefiniować jako różnicę między stanem obecnym a pożądanym. Taiichi Ono, pionier i współtwórca Toyota Production System uważał, że „organizacja, która nie ma żadnych problemów, ma poważny problem” [10]. I jest to prawda, ponieważ ignorowanie istniejących nieprawidłowości generuje kolejne. Zatem, każdy problem powinno się rozwiązywać już na najniższym szczeblu czy etapie, aby nie nawarstwiał się na dalszych. W systemie zarządzania Toyoty nie chodzi o osiąganie rezultatów poprzez ciężką pracę, ale przez stwarzanie pracownikom możliwości myślenia i bycia kreatywnym. Jak mawiał Ohno „ludzie idą do Toyoty, nie dlatego aby pracować, ale aby myśleć" [9]. Stwierdzenie to wyraża filozofię i sposób podejścia do zarządzania ludźmi, który jest nastawiony przede wszystkim na wykorzystanie potencjału i możliwości intelektualnych pracowników, w tym zdolności kreatywnego i twórczego myślenia.

Toyota jest dobrym przykładem na to, jak skutecznie wdrażać metody rozwiązywania problemów w procesach produkcyjnych $[8,12]$. Prezentuje kulturę prowadzenia działalności nastawioną na ciągłe doskonalenie. Sposób, w jaki Toyota zarządza przedsiębiorstwem od lat stanowi wzór dla wielu zakładów, i to nie tylko produkcyjnych. Coraz więcej firm usługowych, szpitali, szkół i uczelni korzysta z metod i narzędzi szczupłego zarządzania. Jednym z sekretów zarządzania Toyoty jest sposób myślenia o problemach i nabywaniu wiedzy podczas ich rozwiązywania, tak aby w przyszłości lepiej planować, podejmować decyzje i wprowadzać działania. Kluczowe jest zatem odpowiednie podejście do problemu, gruntowne jego przeanalizowanie, znalezienie najlepszego rozwiązania i uczenie się po drodze w myśl zasady, że każdy problem jest możliwością do doskonalenia.

\section{Uwarunkowania procesu rozwiązywaniu problemów}

Zależność między problemem a rozwiązaniem jest oczywista. Podczas rozwiązywania problemów należy wykorzystywać kreatywność pracowników. Jest ona podstawą działań prowadzących od określenia problemu do znalezienia rozwiązania - rys. 1 .

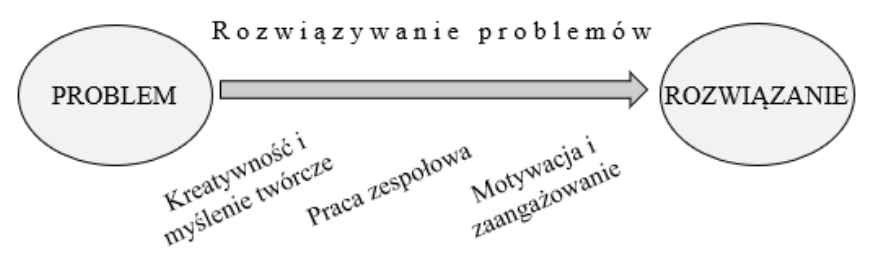

Rysunek 1. Uwarunkowania rozwiązywania problemów

Kreatywność jest cechą ludzi, ściśle powiązaną $\mathrm{z}$ ich kompetencjami oraz nastawieniem. Prof. Ruth Noller [5] zaproponowała symboliczną formułę 
zrozumienia kreatywności, która pokazuje jej interakcję z codziennymi aspektami życia. Kreatywność $(C)$ i związane z nią osiąganie twórczych wyników jest funkcją nastawienia człowieka $\mathrm{w}$ trzech aspektach: wiedzy (K), jaką dana osoba posiada, możliwością użycia wyobraźni (I) do generowania nowych pomysłów oraz zastosowania krytycznej oceny (E), aby wybrać i rozwinąć najbardziej korzystny i obiecujący pomysł. Zgodnie z tym:

$$
C=f_{a}(K, I, E)
$$

gdzie:

$$
\begin{aligned}
& \text { C (Creativity }) \text { - kreatywność, } \\
& \text { a (attitude }) \text { - nastawienie, } \\
& \text { K }(\text { Knowledge }) \text { - wiedza, } \\
& \text { I (Imagination }) \text { - wyobraźnia, } \\
& \text { E (Evaluation }) \text { - ocena. }
\end{aligned}
$$

Wiedza stanowi element wejścia (wkład) do procesu twórczego, który w szerszym ujęciu opiera się na połączeniu nieskrępowanej wyobraźni z krytyczną oceną. Niektórzy eksperci uważają [13], że zdolność ludzi do zmiany i kierowania procesem myślowym - pomiędzy myślami rozmytymi (czyli wyobraźnią) a myślami ukierunkowanymi (czyli oceną) - przyczynia się do twórczej eksplozji. Warto dodać, że istotnym elementem postawy twórczej jest umiejętność kierowania osądami i oceną w celu dostrzeżenia nowych interesujących możliwości.

\section{Zespołowe i kreatywne rozwiązywanie problemów}

\subsection{Wybrane metody i techniki kreatywności}

Efektywne rozwiązywanie problemów jest wynikiem stosowania metod, które aktywują kreatywność jednostek i całych zespołów. Istnieje wiele metod i technik pobudzania kreatywności, które można wykorzystać do twórczego rozwiązywania problemów z zakresu zarządzania i inżynierii produkcji.

Najbardziej znana i popularna w zastosowaniu jest burza mózgów, z różnymi jej odmianami jak np.: dyskusja Philips 66, technika 635, burza mózgów stop and go, odwrócona burza mózgów [14]. W dyskusji Philips 66 tworzy się 6-osobowe grupy. Każda z nich w ciągu 6 minut przeprowadza aktywną burzę mózgów, po czym grupy dzielą się pomysłami. Proces można powtarzać kilkukrotnie. Technika 635 polega na tym, że w 6-osobowej grupie każda osoba zapisuje 3 pomysły w ciągu 5 minut. Po tym czasie osoby przekazują sobie kartki, np. zgodnie z ruchem wskazówek zegara, aby dalej generować nowe albo rozwijać już podane pomysły. Cykl powtarza się 6-krotnie, w efekcie czego przez pół godziny może zostać wytworzonych bardzo dużo pomysłów do przedyskutowania. W burzy mózgów stop and go grupa kilkukrotnie przełącza się między czasem podawania pomysłów (3-5 minut), a czasem przerwy na zebranie myśli, zastanowienie się nad dotychczasowymi pomysłami (3-5 minut). Z kolei w odwróconej burzy mózgów zamiast pytać o to ,,jak rozwiązać problem” zadaje się pytania typu „co powoduje problem”, dzięki czemu z wyprzedzeniem można rozpoznać luki w działaniach, zanim zostaną one wprowadzone. 
Podsumowując, celem burzy mózgów jest wygenerowanie jak największej liczby pomysłów, spośród których można wybrać najlepsze rozwiązania. Metoda polega na swobodnym podejściu do rozwiązywania problemów i jest związana $\mathrm{z}$ myśleniem lateralnym, tzw. „myśleniem w bok” [11]. Burzę mózgów można wykorzystać na różnych etapach rozwiązywania problemów, m.in. do poszukiwania przyczyn nieprawidłowości, generowania pomysłów usprawnień.

Kwiat lotosu to metoda szukania pomysłów w sposób bardziej zorganizowany. Problem w postaci tematu centralnego jest umieszczony w środku, a pomysły jak płatki kwiatu są naokoło niego równomiernie zbierane, a następnie dalej rozwijane w iteracyjny sposób za pomocą obszarów rozwiązań lub powiązanych tematów. Pierwsze rozwinięcie pozwala uzyskać osiem kategorii pomysłów, które dla kolejnych rozwinięć są głównymi tematami. Cechą charakterystyczną metody jest opracowanie różnych podejść i przyjęcie wielu perspektyw widzenia, co powoduje otwarcie się na nowe możliwości. Kwiat lotosu można interpretować jako pewien geometryczny wzór [3]. Można go też porównać do techniki mapowania myśli. Podobnie jak w innych metodach kreatywnego myślenia celem jest zebranie w możliwie krótkim czasie wielu innowacyjnych pomysłów.

\subsection{Zespoły i praca zespołowa w rozwiązywaniu problemów}

W twórczym rozwiązywaniu problemów ważna jest praca zespołowa. Zespół to grupa ludzi, którzy poprzez wykonywane zadania oraz posiadane umiejętności wzajemnie się dopełniają, tak aby jak najlepiej zrealizować wspólny cel [1]. Zespoły mogą się różnić strukturą, charakterem oraz wymaganiami względem poszczególnych członków - związane jest to z rodzajem i celem danego zespołu. Niezależnie od tego, wyniki pracy zespołu uważa się za bardziej efektywne od wyników pracy pojedynczych jednostek, pod warunkiem prawidłowego doboru osób do zespołu uwzględniającego m.in. podział ról i zadań $[2,4]$. Jak podkreślają niektórzy autorzy [7], podczas doboru osób do zespołów ukierunkowanych na kreatywną i innowacyjną działalność należy zwracać uwagę nie tyle na kompetencje techniczne, ale cechy osobowościowe i mentalne kandydatów. Można wyróżnić kilka istotnych czynników, dzięki którym zespół uzyskuje dobre wyniki. Są to w szczególności następujące [6]:

- $\quad$ zespół integruje różne doświadczenia i umiejętności, które ułatwiają podjęcie wielowymiarowych wyzwań dotyczących podnoszenia jakości wyrobów i usług, ulepszeń produktów, metod, procesów;

- rozwija się komunikacja wewnątrz zespołu za sprawą wspólnych celów i sposobów postępowania, co sprzyja bardziej efektywnemu rozwiązywaniu problemów i podejmowaniu inicjatyw;

- $\quad$ zespół cechuje się niepowtarzalnym wymiarem społecznym zbudowanym na wzajemnym zaufaniu i nauce, co zwiększa efektywność pracy.

Metody kreatywności i twórczego myślenia w większości wymagają współpracy, współdziałania, dyskusji, wymiany spostrzeżeń oraz pełnego zaangażowania wszystkich członków zespołu.

\subsection{Metodyka zespołowego rozwiązywania problemów}

Zespołowe podejście do rozwiązywania problemów jest charakterystyczne w systemie zarządzania Toyoty. Raport A3 opracowany przez Toyotę jest 
uniwersalnym narzędziem, które można wykorzystać do zespołowego rozwiązywania problemów na każdym szczeblu i w każdym obszarze firmy [12]. Motywuje pracowników do dogłębnego zbadania i poznania problemu, aby znaleźć przyczynę źródłową i lepiej zaadresować środki zaradcze. Może być również stosowany jako narzędzie do monitorowania i raportowania statusu projektu.

A3 standardowo obejmuje osiem kroków przedstawionych na rys. 2. Ułożone są one zgodnie z cyklem Deminga, przy czym najwięcej działań związanych jest z etapem planowania. Staranne planowanie pozwala gruntownie przemyśleć problem, zbadać jego przyczyny i uzgodnić najlepsze rozwiązanie, tak aby w jak największym stopniu uniknąć zakłóceń i problemów na etapie wdrażania. Zasada „podejmować decyzje powoli, wdrażać szybko" [8] jest charakterystyczna dla filozofii zarządzania Toyoty.

\begin{tabular}{|l|l|}
\hline PLAN & $\begin{array}{l}\text { PLAN / DO } \\
\text { 1. Opis problemu } \\
\text { 2. Obecna sytuacja } \\
\text { 3. Cele } \\
\text { 4. Analiza przyczyn } \\
\text { 5. Proponowane działania }\end{array}$ \\
\hline \hline $\begin{array}{l}\text { CHECK } \\
7 . \text { Monitorowanie wyników }\end{array}$ \\
\hline $\begin{array}{l}\text { ACT realizacja) } \\
\text { 8. Dalsze działania }\end{array}$ \\
\hline
\end{tabular}

Rysunek 2. Etapy rozwiązywania problemów w kontekście metodyki A3 i PDCA

Podczas rozwiązywania problemów z wykorzystaniem A3 można zastosować różne metody i techniki kreatywnego myślenia, zwłaszcza na etapach szukania przyczyn problemu oraz proponowania rozwiązań. Techniki te opierają się na pracy grupowej.

\section{Zastosowanie technik zespołowego i kreatywnego podejścia do rozwiązania przykładowego problemu z zakresu inżynierii produkcji}

Rozpatrywany problem miał miejsce w dziale zakupów przedsiębiorstwa produkcyjnego. Był to zbyt długi czas związany z wprowadzeniem nowego dostawcy do systemu informatycznego, co w efekcie powodowało opóźnienia w składaniu zamówień, jak i samej produkcji. W rozwiązaniu tego problemu wykorzystano zespołowe techniki kreatywności i twórczego myślenia. Utworzono zespół ds. rozwiązywania problemu. Zespół ten składał się z pięciu pracowników działu zakupów i zaopatrzenia, którzy w ramach codziennej pracy często stykali się z tym problemem oraz lidera zakupów, który przewodniczył całemu projektowi.

Kluczowymi etapami rozwiązywania problemu było znalezienie przyczyn jego występowania i zaproponowanie rozwiązań w postaci działań zaradczych. W ramach tego pierwszego zastosowano odmianę burzy mózgów - technikę 635, która w relatywnie krótkim czasie pozwoliła zebrać dużą liczbę potencjalnych przyczyn problemu. Następnie, na podstawie najbardziej prawdopodobnych przyczyn zaproponowano środki zaradcze. Na etapie tym posłużono się metodą kwiatu lotosu - rys. 3. Na środku napisano główny temat czyli problem. Pierwszym krokiem w metodzie było zapełnienie pierwszych płatków kwiatu - były to główne pomysły od A do F, które następnie zostały rozwinięte w kolejne płatki - bardziej szczegółowe 
rozwinięcia pomysłów głównych, czyli A.1, A.2, itd. Nad właściwą i owocną pracą zespołu czuwał lider, dzięki czemu w efekcie zebrano wiele ciekawych i konkretnych pomysłów na rozwiązanie analizowanego problemu.

\begin{tabular}{|c|c|c|}
\hline 1 & 2 & 3 \\
\hline 8 & $\mathrm{~A}$ & 4 \\
\hline 7 & 6 & 5 \\
\hline
\end{tabular}

\begin{tabular}{|c|c|c|}
\hline 1 & 2 & 3 \\
\hline 8 & $\mathrm{~B}$ & 4 \\
\hline 7 & 6 & 5 \\
\hline & $\uparrow$ \\
\hline
\end{tabular}

\begin{tabular}{|l|l|l|}
\hline 1 & 2 & 3 \\
\hline 8 & $\mathrm{C}$ & 4 \\
\hline 7 & 6 & 5 \\
\hline
\end{tabular}

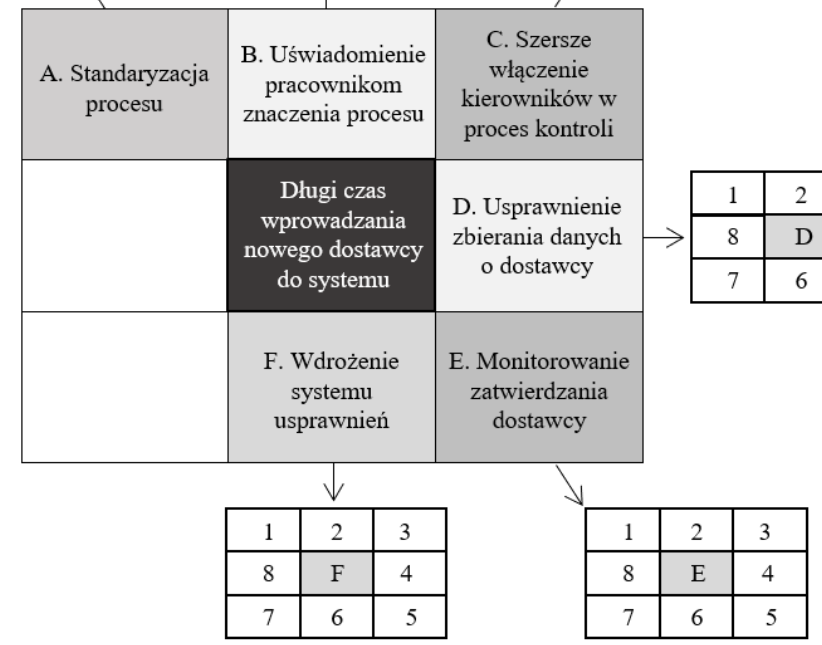

Rysunek 3. Kreowanie pomysłów z wykorzystaniem metody kwiatu lotosu

Spośród zaproponowanych rozwiązań szczegółowych dla każdego pomysłu głównego $\mathrm{A} \div \mathrm{F}$, wybrano te, które w pierwszej kolejności należy zastosować (tab. 1), i opracowano dla nich plan wdrożenia.

Tabela 1. Proponowane środki zaradcze zebrane na podstawie „,kwiatu lotosu”

\begin{tabular}{|l|l|l|}
\hline Rozwiązanie główne & Rozwiązanie szczegółowe & Korzyści \\
\hline A. Standaryzacja procesu & $\begin{array}{l}\text { A.2. Opracowanie norm } \\
\text { czasowych }\end{array}$ & $\begin{array}{l}\text { Motywacja pracowników do } \\
\text { terminowości zadań }\end{array}$ \\
\hline $\begin{array}{l}\text { B. Uświadomienie } \\
\text { pracownikom znaczenia } \\
\text { procesu }\end{array}$ & $\begin{array}{l}\text { B.2. Lista materiałów do } \\
\text { zamówienia }\end{array}$ & $\begin{array}{l}\text { Kontrola czasu realizacji } \\
\text { zamówień }\end{array}$ \\
\hline $\begin{array}{l}\text { C. Szersze włączenie } \\
\text { kierowników w proces } \\
\text { kontroli }\end{array}$ & $\begin{array}{l}\text { C.2. Kontrola każdego } \\
\text { etapu zakładania dostawcy }\end{array}$ & $\begin{array}{l}\text { Kontrola etapów procesu - } \\
\text { możliwość bieżącego } \\
\text { reagowania na zakłócenia }\end{array}$ \\
\hline $\begin{array}{l}\text { D. Usprawnienie zebrania } \\
\text { danych od dostawcy }\end{array}$ & $\begin{array}{l}\text { D.1.Wysyłanie formularza } \\
\text { do dostawcy }\end{array}$ & $\begin{array}{l}\text { Oszczędność czasu przy } \\
\text { wprowadzaniu danych }\end{array}$ \\
\hline $\begin{array}{l}\text { E. Monitorowanie } \\
\text { zatwierdzenia dostawcy }\end{array}$ & E.2. Alert informujący & Usprawnienie komunikacji \\
\hline $\begin{array}{l}\text { F. Wdrożenie systemu } \\
\text { usprawnień }\end{array}$ & $\begin{array}{l}\text { F.5.Centralne śledzenie } \\
\text { przepływu }\end{array}$ & Monitorowanie na bieżąco \\
\hline
\end{tabular}


Po wdrożeniu działań zaradczych, aby zweryfikować ich skuteczność, wprowadzono monitorowanie i kontrolę procesu, aby problem nie pojawił się ponownie. Ustalono także, że każda z osób zespołu będzie przez okres najbliższych kilku miesięcy skupiać się na monitorowaniu wprowadzania nowego dostawcy i zwracać uwagę czy nie pojawiają się jakieś inne niezgodności.

\section{Podsumowanie}

Problemy stanowią nieodłączny element funkcjonowania każdego przedsiębiorstwa, bez względu na wielkość, branżę, stosowane koncepcje i techniki zarządzania. Wiąże się to $\mathrm{z}$ niedoskonałością istniejących w firmie procesów i systemów, które powinny być ciągle doskonalone. Jest to możliwe pod warunkiem, że w przedsiębiorstwie będzie odpowiednia kultura organizacyjna zorientowana na motywowanie pracowników do ujawniania błędów i ich dogłębnego rozwiązywania, zamiast ukrywania problemów i ,gaszenia pożarów”. W kulturze tej ważne jest, aby nauczyć ludzi widzieć i traktować problemy nie jako coś niepożądanego, czego należy unikać, ale jako szansę ciągłego rozwoju.

Stosowanie zespołowych metod i technik kreatywności w rozwiązywaniu problemów daje wiele korzyści, m.in.:

- $\quad$ większą aktywność i udział pracowników w usprawnianiu (kaizen),

- tworzy kulturę ciągłego doskonalenia.

Rozwiązywanie problemów w grupach i zespołach jest także szczególnie korzystne ze względu na efekt synergii. Korzyści zespołowego postępowania są wyraźnie widoczne szczególnie wówczas, gdy potrzebne są różnorodne umiejętności, doświadczenia, opinie, punkty widzenia.

\section{LITERATURA}

1. ADAIR J.: Tworzenie zespołów i motywacja według Johna Adaira. Oficyna a Wolters Kluwer business, Warszawa 2009.

2. BELBIN R. M: Twoja rola w zespole. Gdańskie Wydawnictwo Psychologiczne, Gdańsk 2003.

3. EKLUND A.: Brainstorm Technique: Lotus Blossom. Available on: https://andyeklund.com/brainstorm-technique-lotus-blossom/, 29.09.2021.

4. GELLERT M., NOWAK K.: Zespół. Gdańskie Wydawnictwo Psychologiczne, Gdańsk, 2008.

5. ISAKSEN S. G., DORVAL K. B., TREFFINGER D. J.: Creative Approaches to Problem Solving: A Framework for Innovation and Change. SAGE Publications, Thousand Oaks, California 2011.

6. KATZENBACH J.R., SMITH D.K.: Siła zespołów. Wpływ pracy zespołowej na efektywność organizacji, Oficyna Ekonomiczna, Dom Wydawniczy ABC, Kraków 2001.

7. KOWALEWSKI K.: Formowanie zespołu a jego innowacyjność. Zeszyty Naukowe Politechniki Śląskiej, Seria Organizacja i Zarządzanie, z. 130(2018).

8. LIKER J. K., HOSEUS M.: Kultura Toyoty: serce i dusza filozofii Toyoty. MT Biznes, Warszawa 2009. 
9. LIKER J.K., ROSS K.: The Toyota way to service excellence: Lean transformation in service organization. McGraw Hill Professional, New York 2016.

10. PAKDIL F.: Six Sigma for students: A problem-solving methodology. Springer Nature Switzerland AG, 2020.

11. RAWLINSON J. G.: Creative thinking and brainstorming. Routledge, New York, 2017.

12. SHOOK J.: Zarządzać znaczy uczyć. Rozwiązywanie problemów i rozwój pracowników z wykorzystaniem metody A3, Lean Enterprise Institute Polska, Wrocław 2010.

13. Knowing - Understanding the creative mind, https://us.sagepub.com/sites/default/files/upmassets/81469_book_item_81469.pdf, 14.09.2021.

14. The Ultimate Guide To Mastering Team Brainstorming, https://stormboard.com/blog-archive/the-ultimate-guide-to-mastering-teambrainstorming, 12.09.2021. 